\title{
Characterization of Alluvial Gold Bearing Sediments of Betare Oya District-East Cameroon, Implication for Gold Exploration and Recovery
}

\section{Germain Marie Monespérance Mboudou ${ }^{*}$, Kennedy Folepai Fozao², Olivier Annoh Njoh², Christopher Mbaringong Agyingi²}

${ }^{1}$ Economic Geology Unit, Department of Geology, University of Buea, Buea, Cameroon

${ }^{2}$ Sedimentology and Petroleum Geolgy/Engineering Unit, Department of Geology, University of Buea,

Buea, Cameroon

Email: *mboudougermain@yahoo.fr

How to cite this paper: Mboudou, G.M.M., Fozao, K.F., Njoh, O.A. and Agyingi, C.M. (2017) Characterization of Alluvial Gold Bearing Sediments of Betare Oya DistrictEast Cameroon, Implication for Gold Exploration and Recovery. Open Journal of Geology, 7, 1724-1738.

https://doi.org/10.4236/ojg.2017.711115

Received: October 25, 2017

Accepted: November 27, 2017

Published: November 30, 2017

Copyright (c) 2017 by authors and Scientific Research Publishing Inc. This work is licensed under the Creative Commons Attribution International License (CC BY 4.0).

http://creativecommons.org/licenses/by/4.0/

\begin{abstract}
Field studies (location Au pits, sampling of different layers of sedimentary sequences filling the pits, panning of sediments), litho-stratigraphic investigations, grain size analysis and outlining of depositional conditions revealed a characteristic fining upward sequence in all the sections of $08 \mathrm{Au}$-pits within the Betare Oya basin. A typical profile is 2.5 to $4.5 \mathrm{~m}$ thick and is composed of a 30 to $50 \mathrm{~cm}$ organic topsoil layer, underlain by a $1.5 \mathrm{~m}$ thick reddish brownish gold free saprolite, which is underlain by $1.5 \mathrm{~m}$ sandy section. From litho-stratigraphic investigations and grain size analysis results a quartz dominated gravelly $1.4 \mathrm{~m}$ thick layer consisting in boulders $(275 \mathrm{~mm})$, cobbles (2$<20 \mathrm{~mm}$ ) and subrounded pebbles $(28-38 \mathrm{~mm}$ ) mixed with sand grains $(0.9$ $1.5 \mathrm{~mm})$ and silt $(0.01-0.02 \mathrm{~mm})$. Pyrite, chalcopyrite and arsenopyrite are minor minerals and could be referred as to $\mathrm{Au}$ pathfinders (As, $\mathrm{Fe}, \mathrm{Cu}$ ). This layer overlays paleo-Proterozoic basement rocks (Nyong series) and is overlain by a poorly sorted sandy layer containing rounded whitish quartz grains and plagioclase fractions $(\mathrm{Ca}, \mathrm{Na})$, minor silts $(0.02-0.2 \mathrm{~mm})$, gravel and feldspar (K) leached from granitic plutons along shear zones in the area. The saprolite horizon overlaying the sandy layer derives from weathering and leaching of basement rocks under warm-humid climatic conditions. From gold grain count, the gravelly layer is the main productive horizon. Its upper layer $(0.5 \mathrm{~m})$ yields $02 \mathrm{Au}$ grains per $\mathrm{Kg}$ of sampled materials while the 1 $\mathrm{m}$-tick lower layer contains up to $34 \mathrm{Au}$-grains per sample and $13 \mathrm{~g}$ rains in 1 $\mathrm{Kg}$ of sampled materials. The sandy layer follows with averagely $02 \mathrm{Au}$ grains
\end{abstract}


per $\mathrm{Kg}$ as indication of partial leaching of primary mineralized rocks. $\mathrm{Au}$ concentration at depth (sandy and gravelly layers) is due to physical and chemical remobilization of $\mathrm{Au}$ in the secondary environment of deposition. $\mathrm{Au}$ is lithologically controlled and could be an important exploration factor in the study area. The calculated aspect ratios for pebbles from the gravelly and sandy layers disclosed two polynomial trends: 1) $\mathrm{y}=-0.0148 \mathrm{x}^{2}+1.2187 \mathrm{x}+$ 2.0344, $\mathrm{R}^{2}=0.6929$ (sandy layer); 2) $\mathrm{y}=0.0617 \mathrm{x}^{2}+1.0849 \mathrm{x}+0.8097, \mathrm{R}^{2}=$ 0.8694 (gravelly layer); and $y>R^{2}$ is satisfied in both cases. This implies that $\mathrm{Au}$ recovery from these layers could be effective through gravity separation using sieves mounted on classifiers of $7 \mathrm{~cm}$ (sandy layer) and $10 \mathrm{~cm}$ (gravelly layer) diameter.

\section{Keywords}

Betare Oya, Aspect Ratios, Au Grains Yield, Alluvial Sediments, Pull-Apart Basin

\section{Introduction}

All works done in East Cameroon before the year 2000 were limited to regional geological studies and minor mineral exploration activities ( $\mathrm{Fe}$ and Ni-Co). The first report on gold in the Eastern part of Cameroon was written by [1] although the precious metal has been mined traditionally for decades. Present interest for gold in the region is linked to the revised Cameroon Mining code of 2004. This resulted to a kind of "gold rush" in Batouri, Garoua Boulaye and the Betare Oya district [2]. In this district eighteen (18) small gold pits emerged. Twelve pits are operational and six were abandoned. Gold is alluvial with evidence of primary accumulation in different quartz veins [2]. Secondary alluvial gold is generally found in Proterozoic metasediments of the Lom Series [3]. The gold potential is relatively high: $0.39-4.5 \mathrm{~g} /$ ton after [4] but the gold recovery methods based on combined traditional (separation of heavy mineral fractions from the light ones using manual gravity shaking tables or by washing and panning the alluvial materials carried from streams) and much modern techniques (use of electric shaking tables, classifiers and separators) are not appropriate and need to be improved. Gold exploration should be intensified and research methods diversified. In this context, it is necessary to understand the depositional and sedimentation conditions in the Betare Oya basin and to determine important geotechnical parameters of the Au bearing sediments. This work will contribute in defining the conditions of sedimentation, lithological setting, particle size, aspect ratio of pebbles from the Au horizons as well as their thickness and finally the gold grains count in different horizons in view to optimize the gold extraction from sediments. These may serve as a basis for gold exploration and recovery within the Lom basin and especially the area of study. 


\section{Geologic Context}

\subsection{Regional Geology}

The Betare Oya area is part of the Neoproterozoic (700 - $1100 \mathrm{Ma})$ volcano-sedimentary formations of Cameroon or schist belts referred to as the lower Lom series [5] [6]. These formations occur discordantly on the Pan-African basement made up of migmatites and granitic to ortho-gneissic and biotite rich rocks. They are confined to the NE-SW trending shear zones as part of the Central African and Cameroon shear zone system [7] along which granitic plutons are common (Figure 1). The Betare Oya gold field is found within a major shear zone that represents extentional relays, oblique to the Sanaga fault line (Fig. 1). This structure is transtentional situated within grabens and horsts formed during sinistral shearing, displaying features similar to those of pull-apart basins [7] [8]. This basin was probably filled by eroded and transported materials from N30 E-N40-E striking gold bearing quartz veins [4] and slightly metamorphosed quartzites and granitoids [9]. Alluvial gold is remobilsed in the metasediments hosted in biotite-, sericite- and chlorite-schists as well as in quartzites and shales [10] [11].

\subsection{Channel Sedimentation in the Lom Basin}

The present Lom basin is composed of low-grade metasediments and volcanoclastic schists with some gold bearing sequences generally associated with

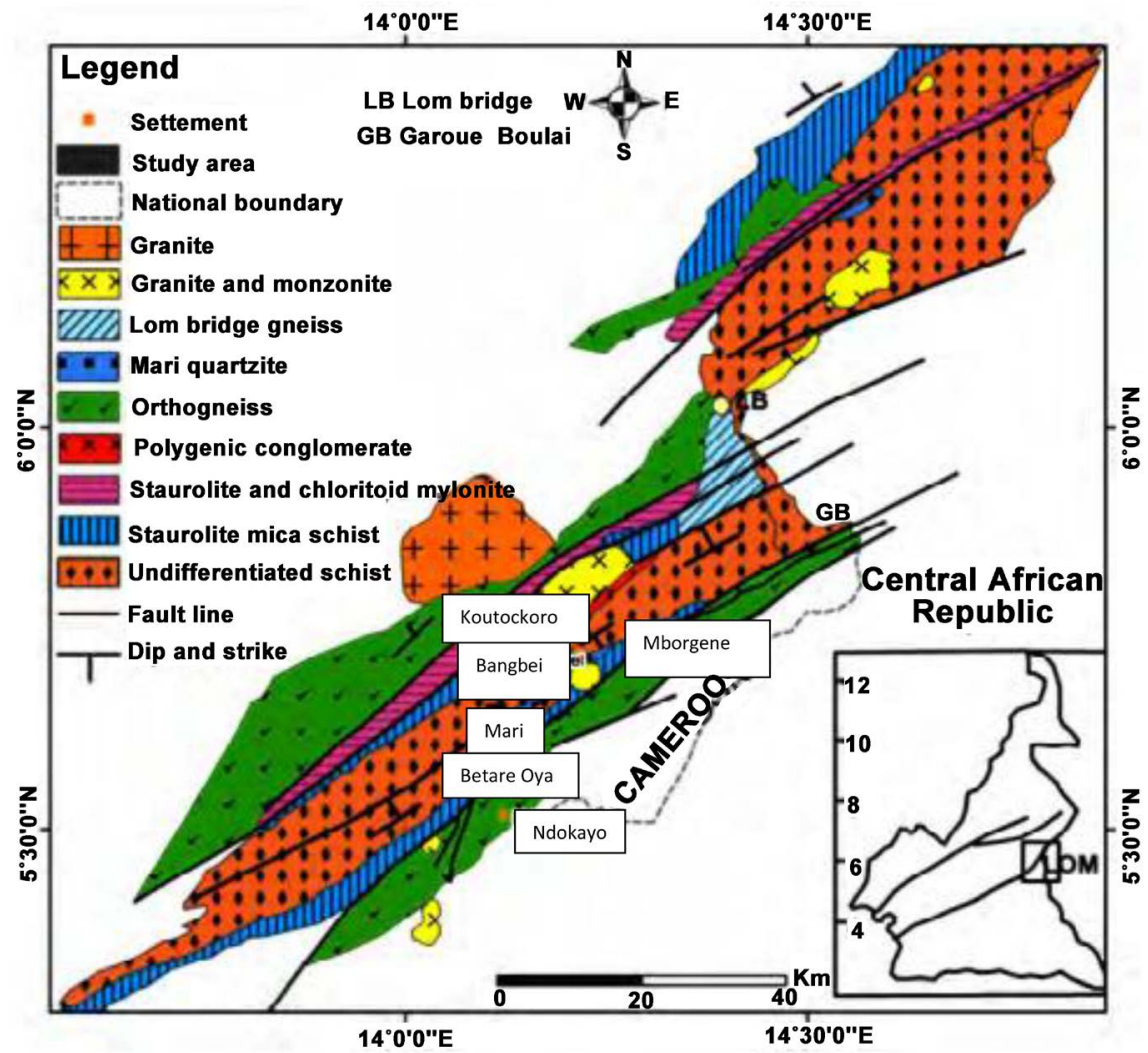

Figure 1. Geologic map of Betare Oya and environs (Modified after Suh et al., 2006). 
subordinate conglomeritic quartzites. These metasediments resulted from unconsolidated fluvial (alluvial and channel) sedimentation and were subsequently intruded by granitic plutons. As observed in the several gold pits (abandoned and active), the sequences generally exhibit a basal conglomeritic layer directly overlying the black schist metasediments. The conglomerates are overlain by a sandy layer which is also covered by a saprolitic and topsoil layers respectively (Figure 2(a) and Figure 2(b)).

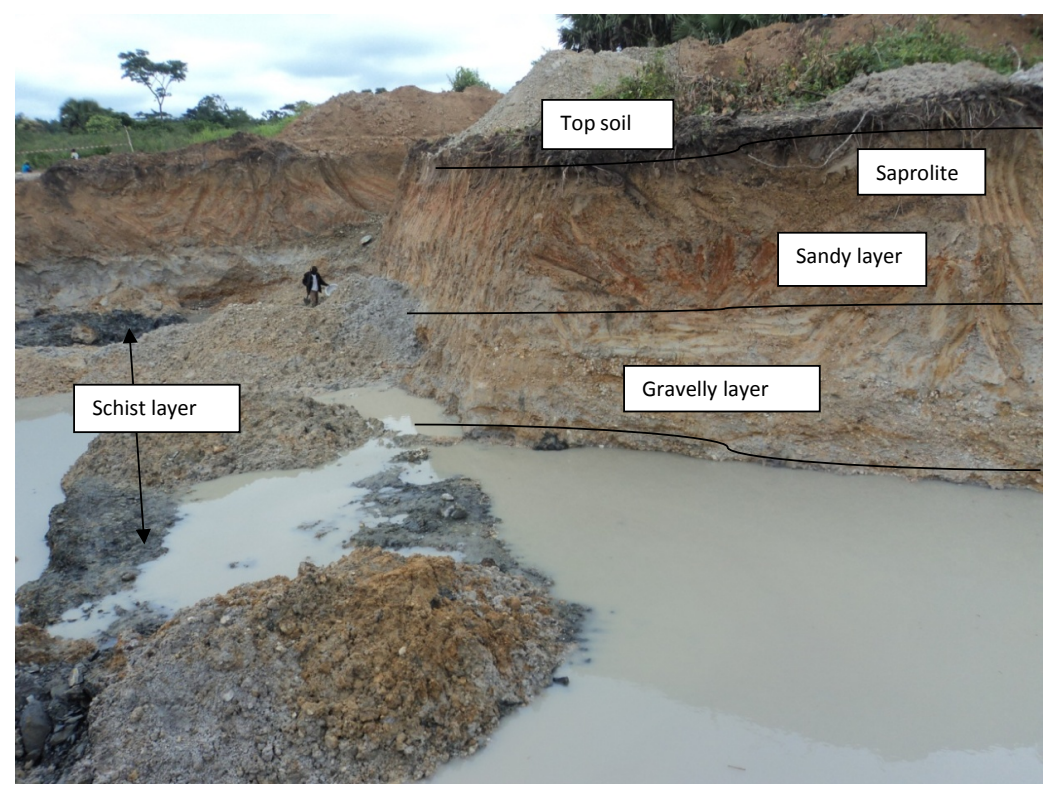

(a)

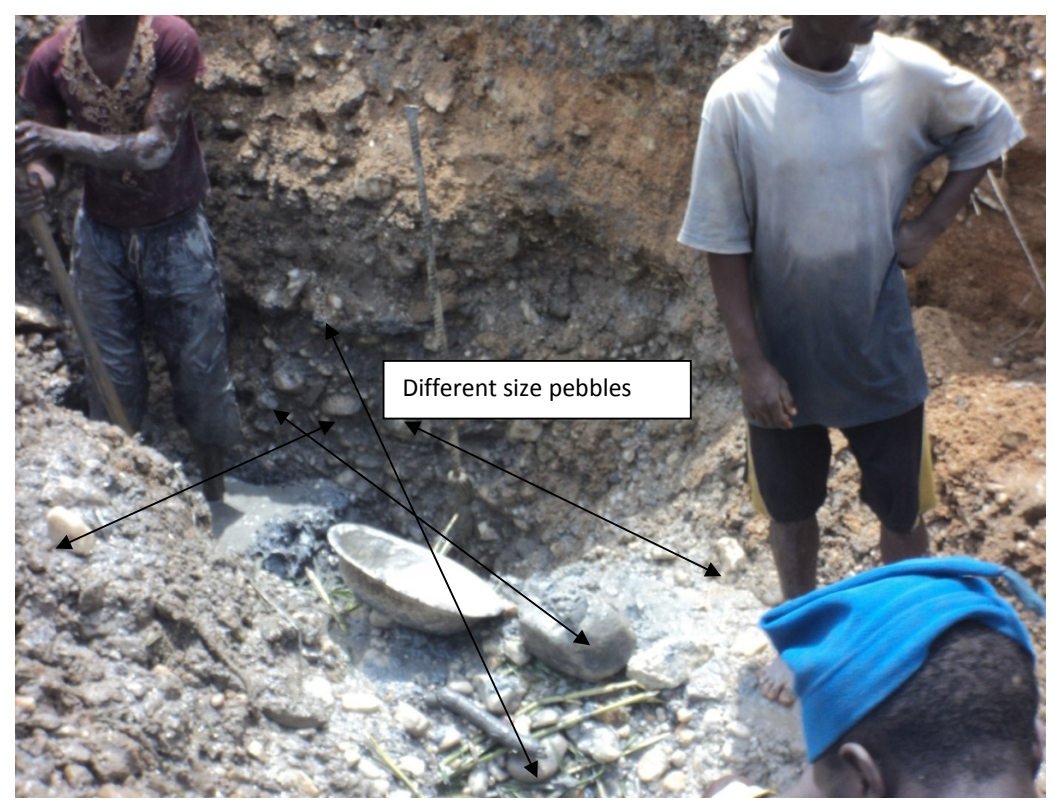

(b)

Figure 2. (a) Picture showing the different horizons of the Mari 2: top soil, saprolite, sandy and Au-bearing gravelly layers; (b) Picture showing gold bearing gravelly layer of pit Mari 1. 
The sedimentation in the study area is basically linked to the Lom River which is the main water body running through the Lom basin. It has several tributaries and intermittent run-offs that actively denudate the surrounding highlands. Primary gold bearing quartz veins [4] including other intrusions are of common occurrence on these surrounding highlands. Huge amounts of eroded debris is thus washed down from these highlands and collected into the Lom River for onward transportation and deposition along its channel and over the floodplain. The location of the gold mining sites (artisanal and industrial) in this basin is linked to the various depositional units, channel or overbank (alluvial) within the Lom River valley. This may indicate that the main river switched its channel severally.

\section{Field Study}

Field investigations were carried out in 12 gold pits of the Betare Oya gold field around Mali village and along the River Mari which is a tributary of the River Lom. Sediments were systematically collected from the surface and streams around the gold pits. These samples were taken to the geologic laboratory of the University of Buea for drying and sieving according to grain size.

Panning of stream sediments was done in the field. Some sediment samples (2 - $3.5 \mathrm{Kg}$ ) were collected from three horizons (gravel, sandy and saprolite) and panned for heavy minerals. The concentrates were labeled and taken to the geologic laboratory of the University of Buea for the counting of gold grains.

In 12 gold pits, each horizon located above the basal schist layer was described and the thickness measured using a metric tape. Different sizes of pebbles were equally collected from each horizon and labeled for the calculation of their aspect ratios.

\section{Laboratory Investigations}

\subsection{Gold Grain Count and Grain Size Analysis}

Concentrates of heavy fractions from each horizon were dried using an oven at $100^{\circ} \mathrm{C}$ and the magnetic fraction was removed using a bar magnet. This was followed by counting of gold grains from the non-magnetic fractions, using a stereoscopic binocular microscope Model "Karl Zeiss Iena”.

For determination of the grain size, sediments and gravelly materials (pebbles) were equally dried for days and sieved using different diameter sieves. These sediments were further sorted out according to their size, shape and color.

\subsection{Aspect ratios of the Pebbles}

The aspect ratio of a shape is the ratio of its longer dimension (longest axis or major axis) to its shorter dimension (shortest axis or minor axis). Such measurements were done for pebbles from the different horizons in four Au-pits of the study area (Tables A1-A6). The values obtained were plotted and displayed on an Excel sheet for a better presentation and interpretation. 


\section{Results and Discussion}

\subsection{Characteristics of the Sedimentary Sequences}

After excavation works, several vertical sequences were exposed and permitted the identification of distinct layers composed of unconsolidated and poorly sorted sandy to gravelly materials. The layers show no evidence of structural signatures like cross-stratifications making it difficult to properly differentiate the various depositional units along the study area. However, a characteristic fining upward sequence prevails in all the sections. The sections generally range between 2.5 and $4.5 \mathrm{~m}$ in height (Figure 3 ). The gravelly layer directly overlying the biotite-mica schists (Lom series) is not well sorted and its particles range in size from boulders $(275 \mathrm{~mm})$ to cobbles $(28-38 \mathrm{~mm})$ and pebbles mixed with sand $(0.9-1.5 \mathrm{~mm})$ and silt $(0.05-0.06 \mathrm{~mm})$. The presence of fine particle size fabric in the basal gravelly layer can be attributed to post-depositional infiltration by sand and silt [12] [13]. This layer is quartz dominated, with minor sulphide minerals such as pyrite, chalcopyrite and arsenopyrite, whose presence in this layer may be an indication of $\mathrm{Au}$ pathfinders (As, $\mathrm{Fe}, \mathrm{Cu}$ ). The sub-rounded shape of the pebbles can be linked to long distance transportation. Au concentration is higher than in other layers. These confirm the nature of the source rocks that have been modified due to climatic and weathering processes as well as the transportation influence on the depositional history of the sediments in the study area [12].

The Au bearing gravelly or basal conglomeratic layer is overlain by a poorly sorted sandy layer. Silt particles $(0.009-0.04 \mathrm{~mm})$ of the sandy layer form the ground mass where rounded whitish quartz sand grains and plagioclase fractions

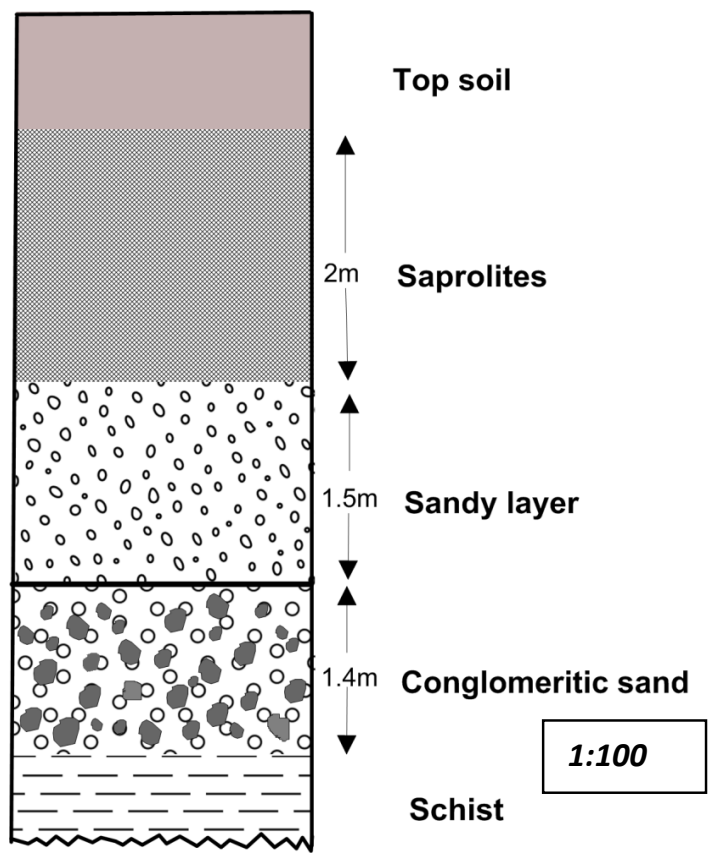

Figure 3. Sketch of lithologic profile of Betare Oya basin. 
$(\mathrm{Ca}, \mathrm{Na})$ dominate with minor gravel as well as feldspar $(\mathrm{K})$ probably leached from granitic plutons along the Batouri, Garoua Boulai Betare Oya shear zone [4].

A thick reddish brown saprolite horizon rich in iron oxides resulting from intense weathering overlies the sandy layer. The saprolite horizon in all mine sites is capped by a thin dark gray and organic rich topsoil layer.

The mining sites along River Mari in the study area are located in abandoned river channels, ox-bow lakes, channel-lag depositional units and the overbank alluvial units. This is an indication of intensive weathering of Au bearing Proterozoic rocks in the Betare Oya district [13], followed by fluvial transportation and deposition [14].

\subsection{Lithological Units and Au grains yield}

From the average gold grains count in all pits of the study area (Table 1) a clear distinction between the saprolite, the sandy and the gravelly (basal conglomeritic) horizons is observed. These correspond to the different units (layers) indicated in the litho-stratigraphic log (Figure 3) of the Betare Oya basin.

The upper saprolite has an average thickness of $2 \mathrm{~m}$ and yields no Au. Only two samples yield one (01) Au-grain each. It could be due to intensive surface weathering of the bedrocks (schist) linked to high humidity and warm climatic conditions [12] that completely leached the valuable elements including $\mathrm{Au}$.

A smooth transition between the lower saprolite and the $1.5 \mathrm{~m}$ thick sandy layer could be indicated by a steady Au-grains count (01 grain) for both horizons. The average gold grains is (02) in the sandy layer and could be interpreted as partial elemental leaching of the primary mineralized rocks or different Au-bearing quartz veins found in the study area or as existence of free Au particles in the samples collected [15] [16].

The gravelly layer with average thickness of $1.4 \mathrm{~m}$ is the main Au productive horizon (Figure 4). It can be subdivided into the upper layer $(0.5 \mathrm{~m})$ with an average of $05 \mathrm{Au}$-grains per sample (02 Au-grains/Kg of materials) and the lower layer $(1 \mathrm{~m})$ with the highest Au-grains count equivalent to 34 grains per sample and 13 grains $/ \mathrm{Kg}$ of materials. The gravelly layer has a low Au content in the upper layer while high $\mathrm{Au}$ content is noted in the lower layer of the same horizon. Most of the $\mathrm{Au}$ in the study area has been retained in this horizon and could be an indication of an earlier (Paleo-Proterozoic) weathering period which probably led to the dissolution of $\mathrm{Au}$ in association with sulfides, quartz and other primary minerals ligands [12] [17]. The Au mineralization is observed in the sandy and gravelly horizons implying a certain lithologic control. It therefore appears that $\mathrm{Au}$ is abundant at depth in the area of study. This confirms a physical and chemical remobilization of Au in secondary environment of deposition [18]. In fact, more stable secondary minerals such as Au are deposited at the bottom of the basin below the saprolite layer and above the fresh rock or basement [18] [19]. 
Table 1. Summarized gold grains count in concentrates from different layers of Mari pits $1-8$.

\begin{tabular}{|c|c|c|c|c|}
\hline $\begin{array}{c}\text { Samplenumber } \\
\text { (concentrate) }\end{array}$ & $\begin{array}{l}\text { Weight of panned } \\
\text { material }(\mathrm{Kg})\end{array}$ & Gold grain count & $\begin{array}{c}\text { Gold grains per } \mathrm{Kg} \\
\text { of material }\end{array}$ & Horizon \\
\hline 02 & 2 & 0 & 0 & \multirow{12}{*}{ Saprolite (upper) } \\
\hline 03 & 2 & 0 & 0 & \\
\hline 09 & 2 & 0 & 0 & \\
\hline 10 & 2.7 & 0 & 0 & \\
\hline 11 & 2.6 & 0 & 0 & \\
\hline 12 & 2.5 & 0 & 0 & \\
\hline 13 & 2.3 & 0 & 0 & \\
\hline 16 & 2.6 & 0 & 0 & \\
\hline 17 & 2.7 & 0 & 0 & \\
\hline 21 & 2 & 0 & 0 & \\
\hline 22 & 2 & 0 & 0 & \\
\hline 27 & 2 & 0 & 0 & \\
\hline 01 & 2.1 & 1 & 1 & \multirow{2}{*}{ Saprolite (lower) } \\
\hline 20 & 2.1 & 1 & 1 & \\
\hline 04 & 2.4 & 2 & 1 & \multirow{7}{*}{ Sandy } \\
\hline 05 & 2.5 & 3 & 1 & \\
\hline 18 & 3 & 2 & 1 & \\
\hline 20 & 2.1 & 1 & 1 & \\
\hline 23 & 2.4 & 2 & 1 & \\
\hline 24 & 2.4 & 3 & 1 & \\
\hline 25 & 2.7 & 2 & 1 & \\
\hline 06 & 2.5 & 4 & 2 & \multirow{5}{*}{ Gravelly(upper) } \\
\hline 08 & 2.6 & 5 & 2 & \\
\hline 19 & 2.7 & 6 & 2 & \\
\hline 26 & 3.4 & 5 & 1 & \\
\hline 28 & 2.7 & 7 & 3 & \\
\hline 07 & 2.2 & 35 & 16 & \multirow{4}{*}{ Gravelly (lower) } \\
\hline 14 & 3 & 27 & 9 & \\
\hline 29 & 2.6 & 38 & 15 & \\
\hline 30 & 2.5 & 35 & 13 & \\
\hline
\end{tabular}

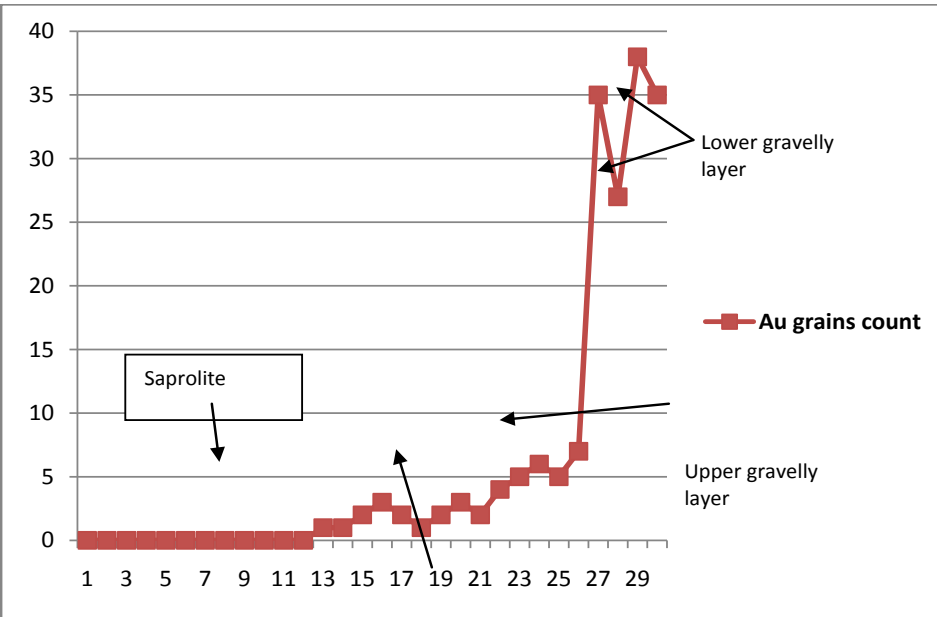

Sandy layer

Figure 4. Diagram showing the variation of Au grain count in different layers of the lithologic profile of Betare Oya. X-axis (samples) and Y-axis (number of Au grains). 


\subsection{Aspect Ratios of the Pebbles from Sandy and Gravelly Horizons}

The diagrams (Figure 5 and Figure 6) show two major trends for the pebble size in the sandy layers as well as in the gravelly layers. The first trend indicates that most of the Au-bearing material in sandy and the gravelly horizons could be obtained using sieves or classifiers with sieving diameters of $2.5 \mathrm{~cm}$ and $7.5 \mathrm{~cm}$ respectively.

The second trend will correspond to sieves and classifiers of bigger diameter sizes $(4.5 \mathrm{~cm}$ and $10 \mathrm{~cm})$ for both sandy and gravelly horizons. The general relation between the pebble length ( $\mathrm{y}$ ) and width $(\mathrm{x})$ is given by the polynomial trend relationships from which the diameter of the sieves derives.

For the two different layers, these relationships are as follows:

Layer 1: 1) $\mathrm{y}=-0.0148 \mathrm{x}^{2}+1.2187 \mathrm{x}+2.0344, \mathrm{R}^{2}=0.6929$

Layer 2: 2) $y=0.0617 x^{2}+1.0849 x+0.8097, R^{2}=0.8694$

The best R-squared values were chosen for the best fits. Using the above relationships and considering the average size of the pebbles (pebble length and width), a projection of the diameter of the sieves mounted on the classifiers for the physical separation of $\mathrm{Au}$ from unwanted sediments could be made if the following conditions are fulfilled using Equation (1) and Equation (2):

- For layer 1 (sandy layer) $y^{1}>\left(R_{1}\right)^{2}$, where ' $x$ ' is the average length of the pebbles, equivalent to $7 \mathrm{~cm} \cdot \mathrm{y}^{1}=9.8401 ;\left(\mathrm{R}_{1}\right)^{2}=0.6929$ thus $\mathrm{y}^{1}>\left(\mathrm{R}_{1}\right)^{2}$.

- For layer 1 (gravelly layer) $y^{2}>\left(R_{2}\right)^{2}$, where ' $x$ ' is the average length of the pebbles, equivalent to $10 \mathrm{~cm} \cdot \mathrm{y}^{2}=17.8287 ;\left(\mathrm{R}_{2}\right)^{2}=0.6929$ thus $\mathrm{y}^{2}>\left(\mathrm{R}_{2}\right)^{2}$.

\section{Conclusions}

The sediments from pits in the study area are 2.5 to $4.5 \mathrm{~m}$ deep, and consist of unconsolidated and poorly sorted sandy to gravelly materials. A typical profile is

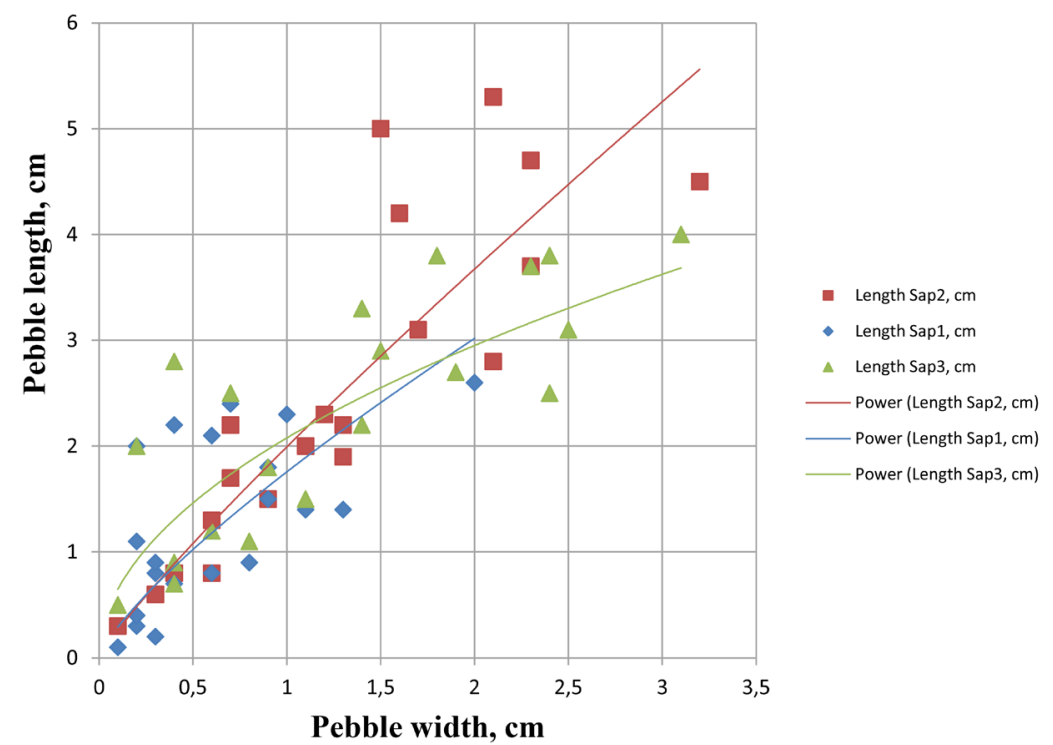

Figure 5. Summarized aspect ratios for the different pebbles in sandy layers from Mari pits $1-8$. The size (values) of pebbles is not homogeneous. 


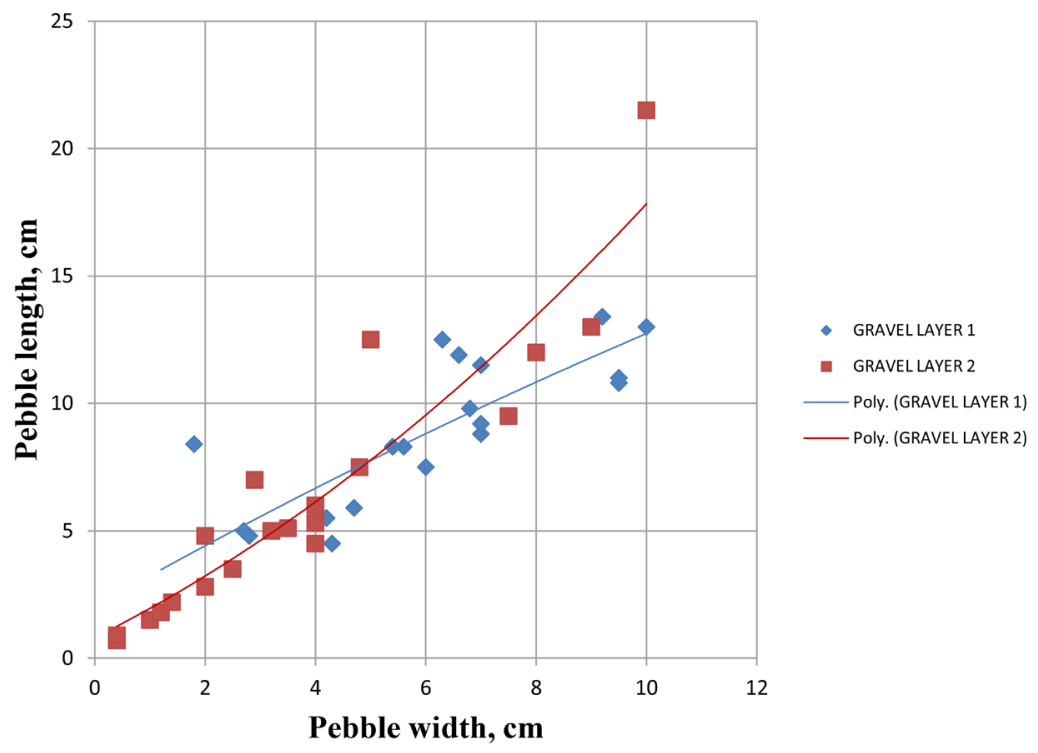

Figure 6. Summarized aspect ratios for the different pebbles in the gravelly layers from Mari pits 1 - 8. The size (values) of pebbles is more or less homogeneous.

composed of a 30 to $50 \mathrm{~cm}$ organic topsoil layer, underlain by a $2 \mathrm{~m}$ thick saprolitic horizon, which is underlain by $1.5 \mathrm{~m}$ sandy section. The quartz dominated gravelly layer with an average thickness of $1.4 \mathrm{~m}$ overlies the biotite-mica schists of the paleo-Proterozoic basement, and consists of boulders $(275 \mathrm{~mm})$, cobbles and pebbles $(28-38 \mathrm{~mm})$ mixed with sand $(0.9-1.5 \mathrm{~mm})$ and silt $(0.05-0.06$ $\mathrm{mm})$.

The saprolite has no Au because of weathering and leaching of valuable elements including Au.

The sandy layer yields averagely 02 gold grains per $\mathrm{Kg}$ of materials resulting from partial elemental leaching of different Au-bearing quartz veins found in the study area.

The gravelly layer is the main Au productive horizon. Its upper layer $(0.4 \mathrm{~m})$ has $05 \mathrm{Au}$-grains per sample (02 Au-grains/Kg of materials) and the lower layer $(1 \mathrm{~m})$ has up to $34 \mathrm{Au}$-grains per sample and 13 grains/Kg of sediments. Most of the $\mathrm{Au}$ in the study area in this horizon could be an indication of Paleo-Proterozoic weathering, which probably led to the dissolution of Au ligands.

The Au mineralization is linked to the deep sandy and gravelly horizons implying a certain lithologic control and can be an important factor for future $\mathrm{Au}$ exploration in the study area.

Au concentration at depth is due to physical and chemical remobilization of $\mathrm{Au}$ in the secondary environment of deposition, where more stable secondary minerals are deposited in warm humid and weathered areas.

The calculated aspect ratios for the pebbles from sandy and gravel horizons disclosed two types of classifiers for gold recovery. The first type corresponds to sieves and classifiers of smaller diameter size $(2.5 \mathrm{~cm}$ and $7 \mathrm{~cm})$; the second type is of bigger diameter size $(4.5 \mathrm{~cm}$ and $10 \mathrm{~cm})$. 


\section{References}

[1] Gerard, G.J. (1954) Notice explicative de la feuille de Batouri-Est (1/500,000). [Notice on East-Batouri (1/500 000) geologic map.] DMG, Yaoundé.

[2] Suh, C.E. and Lehmann, B. (2003) Morphology and Electron-Probe Microanalysis of Residual Gold Grains at Dimako, Southeast Cameroon. Neues Jahrbuch für Mineralogie Monatshefte, 6, 255-275. https://doi.org/10.1127/0028-3649/2003/2003-0255

[3] Bessoles, B. (1969) Synthèse simplifiée des connaissances sur la geologie du Cameroun. [Synopsys of Geology of Cameroon.] DMG Bulletin, 5, 187-218.

[4] Suh, C.E., Lehmann, B. and Mafany, G.T. (2006) Geology and Geochemical Aspects of Lode Gold Mineralization at Dimako-Mboscorro, SE Cameroon. Geochemistry: Exploration, Environment, Analysis, 6, 295-309. https://doi.org/10.1144/1467-7873/06-110

[5] Toteu, S.F., Van Schmus, W.R., Penaye, J. and Nyobé, J.B. (1994) U-Pb and Sm-Nd Evidence for Eburnean and Pan-African High-Grade Metamorphism in Cratonic Rocks of Southern Cameroon. Precambrian Research, 108, 45-73. https://doi.org/10.1016/S0301-9268(00)00149-2

[6] Toteu, S.F., Penaye, J. and Poudjom Djomani, Y. (2004) Geodynamic Evolution of the Pan-African Belt in Central Africa with Special Reference to Cameroon. Canadian Journal of Earth Sciences, 41, 73-85. https://doi.org/10.1139/e03-079

[7] Deruelle, B. and Regnoult, J.M. (1983) Carte Tele-interpretative des linéaments de la République Unie du Cameroun au nord du $4^{\mathrm{e}}$ parallele $(1 / 1,000,000)$. [Interpretation Map of Lineaments of United Republic of Cameroon at $4^{\text {th }}$ Parallel $(1 / 1$ 000,000).] Ministry of Mines and Energy Resources, DMG, Yaoundé.

[8] Gazel, J., Hourcq, V. and Nickles, M. (1956) Reference Notice on 1/1,000,000 Geologic Map of Cameroon. Service Bulletin of Mines and Geology, 2, Yaoundé.

[9] Fletcher, W.K. and Day, S.J. (1989) Behavior of Gold and Other Heavy Minerals in Drainage Sediments: Some Implications for Exploration Geochemical Surveys. Transactions of the Institution of Mining and Metallurgy (Section B: Applied Earth Science), 98, 130-136.

[10] Cassidy, K.F. (1997) Granitoid-Hosted Gold Deposits in the Eastern Yilgarn Craton. In: Cassidy, K.F., Whitaker, A.J., Liu, S.F., Eds., Kalgorlie 97: An International Conference on Crustal Evolution, Metallogeny, and Exploration of the Yilgarn Craton-An Update, Australian Geological Survey, Camberra, 131-136.

[11] Lerouge, C., Cocherie, A., Toteu, S.F., Penaye, J., Milési, J.P., Tchameni, R., Nsifa, E.N., Fanning, C.M. and Doloule, E. (2006) Shrimp U-Pb Zircon Age Evidence for Paleoproterozoic Sedimentation and 2.05Ga Syntectonic Plutonism in the Nyong Group, South-Western Cameroon. Consequences for the Eburnean-Transamazonian belt of NE Brazil and Central Africa. Journal of African Earth Sciences, 44, 413-427. https://doi.org/10.1016/j.jafrearsci.2005.11.010

[12] German, K., Schwartz, T. and Wipki, M. (1994) Mineral Deposit Formation in Phanerozoic Sedimentary Basins of North-East Africa: The Contribution of Weathering. Geologische Rundschau, 83, 187-198.

[13] Butt, C.R.M. (1989) Gold Mobility in the Weathering Environment. International Conference on Prospecting in Arid Terrain, 2nd Part, Eastern Gold Fields, Australia.

[14] Henley, R.W. and Adams, J. (1979) On the Evolution of Giant Gold Placers. Section B, 41-50, 88 p, Inst. Min. Metall., London. 
[15] Wang, W. and Poling, G.W. (1983) Methods for Recovering Fine Placer Gold. CIM Bulletin, 76, 47-56.

[16] Nichol, CH.E. (1986) Exploration for Ore Deposits of the North American Cordillera. Journal of Exploration and Geochemistry, 25, 172-181.

[17] Groves, D.I., Goldfarb, R.J., Gebre-Mariam, M., Hagemann, S.G. and Robert, F. (1998) Orogenic Gold Deposits: A Proposed Classification in the Context of Their Crustal Distribution and Relationship to Other Gold Deposit Types. Ore Geology Reviews, 13, 7-27. https://doi.org/10.1016/S0169-1368(97)00012-7

[18] Lawrence, L.M. (1990) Gold Deposits of the Archean Yilgarn Block, Western Australia: Supergene Gold Mineralization. In: Groves, D.A. and Bennett, J.M., Eds., Nature, Genesis and Exploration Guides, Australia, 157-167.

[19] Hassan Ali, H. (1999) Applications of Geochemical Parameters at the Gebeit Gold Mine Area, NE Sudan: Exploration Criteria and Environmental Impact. W\&T Verlag, Berlin. 


\section{Appendix}

Table A1. Summarized aspect ratios for top soil and saprolite from Au-pits (1 - 8) at Mari.

\begin{tabular}{|c|c|c|c|c|}
\hline Layers & Thickness $(\mathrm{cm})$ & Number of pebbles & Long axis (cm) & Short axis $(\mathrm{cm})$ \\
\hline Top soil & 30 & & & \\
\hline \multirow{20}{*}{ Saprolite } & \multirow{20}{*}{100} & \multirow{20}{*}{20} & 1.6 & 0.6 \\
\hline & & & 1.5 & 0.4 \\
\hline & & & 1.2 & 0.3 \\
\hline & & & 1.3 & 0.2 \\
\hline & & & 1.3 & 0.3 \\
\hline & & & 0.5 & 0.3 \\
\hline & & & 0.6 & 0.3 \\
\hline & & & 0.6 & 0.3 \\
\hline & & & 0.7 & 0.4 \\
\hline & & & 0.5 & 0.2 \\
\hline & & & 0.5 & 0.4 \\
\hline & & & 0.5 & 0.3 \\
\hline & & & 0.6 & 0.4 \\
\hline & & & 0.4 & 0.2 \\
\hline & & & 0.4 & 0.1 \\
\hline & & & 0.3 & 0.2 \\
\hline & & & 0.4 & 0.2 \\
\hline & & & 0.4 & 0.3 \\
\hline & & & 0.3 & 0.2 \\
\hline & & & 0.5 & 0.2 \\
\hline
\end{tabular}

Table A2. Summarized aspect ratios for the sandy layer from Au-pits (1 - 8) at Mari.

\begin{tabular}{|c|c|c|c|c|}
\hline Layer & Thickness $(\mathrm{cm})$ & Number of pebbles & Long axis $(\mathrm{cm})$ & Short axis $(\mathrm{cm})$ \\
\hline \multirow{24}{*}{ Sandy layer } & \multirow{24}{*}{70} & \multirow{24}{*}{24} & 6.5 & 3.6 \\
\hline & & & 4.5 & 2.5 \\
\hline & & & 4.4 & 1.7 \\
\hline & & & 2.4 & 2.1 \\
\hline & & & 3.0 & 0.6 \\
\hline & & & 3.0 & 1.5 \\
\hline & & & 3.2 & 2.0 \\
\hline & & & 2.7 & 1.3 \\
\hline & & & 2.0 & 1.3 \\
\hline & & & 2.4 & 1.6 \\
\hline & & & 1.8 & 1.0 \\
\hline & & & 2.0 & 1.1 \\
\hline & & & 2.1 & 1.3 \\
\hline & & & 1.2 & 0.6 \\
\hline & & & 1.0 & 0.3 \\
\hline & & & 0.9 & 0.1 \\
\hline & & & 1.2 & 0.5 \\
\hline & & & 1.7 & 0.8 \\
\hline & & & 1.0 & 0.4 \\
\hline & & & 0.7 & 0.3 \\
\hline & & & 0.5 & 0.3 \\
\hline & & & 0.6 & 0.2 \\
\hline & & & 0.3 & 0.2 \\
\hline & & & 0.4 & 0.2 \\
\hline
\end{tabular}


Table A3. Summarized aspect ratios for the gravel layer from Au-pits (1 - 8) at Mari.

\begin{tabular}{|c|c|c|c|c|}
\hline Layer & Thickness $(\mathrm{cm})$ & Number of pebbles & Long axis $(\mathrm{cm})$ & Short axis $(\mathrm{cm})$ \\
\hline \multirow{20}{*}{ Gravel layer } & \multirow{20}{*}{90} & \multirow{20}{*}{20} & 8.3 & 5.7 \\
\hline & & & 11.5 & 9.0 \\
\hline & & & 12.5 & 6.1 \\
\hline & & & 7.5 & 6.0 \\
\hline & & & 7.3 & 6.7 \\
\hline & & & 12.0 & 9.0 \\
\hline & & & 11.5 & 7.0 \\
\hline & & & 5.9 & 4.7 \\
\hline & & & 8.8 & 7.0 \\
\hline & & & 9.2 & 7.5 \\
\hline & & & 8.0 & 3.7 \\
\hline & & & 8.3 & 7.0 \\
\hline & & & 8.3 & 5.6 \\
\hline & & & 11.9 & 7.0 \\
\hline & & & 5.5 & 4.2 \\
\hline & & & 4.5 & 4.2 \\
\hline & & & 4.8 & 2.8 \\
\hline & & & 5.0 & 2.7 \\
\hline & & & 2.0 & 1.0 \\
\hline & & & 2.1 & 0.6 \\
\hline
\end{tabular}

Table A4. Summarized aspect ratios for all layers from Au-pits (1 - 4) at Mari.

\begin{tabular}{|c|c|c|c|c|}
\hline Horizon & Thickness $(\mathrm{cm})$ & Number of pebbles & Long axis $(\mathrm{cm})$ & Short axis $(\mathrm{cm})$ \\
\hline \multirow{9}{*}{ Saprolite } & \multirow{9}{*}{35} & \multirow{9}{*}{9} & 0.9 & 0.4 \\
\hline & & & 2.2 & 1.4 \\
\hline & & & 2.0 & 0.9 \\
\hline & & & 1.2 & 0.6 \\
\hline & & & 1.5 & 1.1 \\
\hline & & & 2.4 & 2.4 \\
\hline & & & 1.8 & 0.9 \\
\hline & & & 1.4 & 0.4 \\
\hline & & & 2.5 & 2.4 \\
\hline \multirow{9}{*}{ Sandy layer } & \multirow{9}{*}{60} & \multirow{9}{*}{9} & 3.0 & 2.6 \\
\hline & & & 2.9 & 2.4 \\
\hline & & & 3.7 & 2.4 \\
\hline & & & 2.0 & 2.4 \\
\hline & & & 2.0 & 1.2 \\
\hline & & & 1.0 & 0.6 \\
\hline & & & 0.6 & 0.5 \\
\hline & & & 0.8 & 0.5 \\
\hline & & & 0.5 & 0.4 \\
\hline \multirow{10}{*}{ Gravel layer } & \multirow{10}{*}{160} & \multirow{10}{*}{10} & 5.0 & 4.5 \\
\hline & & & 20 & 1.3 \\
\hline & & & 7.0 & 5.8 \\
\hline & & & 7.3 & 5.5 \\
\hline & & & 4.8 & 3.2 \\
\hline & & & 6.0 & 5.5 \\
\hline & & & 3.0 & 2.5 \\
\hline & & & 3.2 & 2.1 \\
\hline & & & 5.5 & 2.7 \\
\hline & & & 3.5 & 2.0 \\
\hline
\end{tabular}


Table A5. Summarized aspect ratios all layers layer from Au-pits (4 - 6) at Mari.

\begin{tabular}{|c|c|c|c|c|}
\hline Horizon & Thickness $(\mathrm{cm})$ & Number of pebbles & Long axis $(\mathrm{cm})$ & Short axis $(\mathrm{cm})$ \\
\hline \multirow{8}{*}{ Saprolite } & \multirow{8}{*}{160} & \multirow{8}{*}{8} & 0.6 & 0.3 \\
\hline & & & 0.8 & 0.4 \\
\hline & & & 3.1 & 1.7 \\
\hline & & & 2.3 & 1.2 \\
\hline & & & 3.7 & 2.3 \\
\hline & & & 0.3 & 0.1 \\
\hline & & & 5.0 & 1.5 \\
\hline & & & 1.3 & 0.6 \\
\hline \multirow{8}{*}{ Sandy layer } & \multirow{8}{*}{150} & \multirow{8}{*}{8} & 1.7 & 1.2 \\
\hline & & & 3.5 & 1.4 \\
\hline & & & 2.5 & 0.1 \\
\hline & & & 0.3 & 0.1 \\
\hline & & & 1.0 & 0.5 \\
\hline & & & 1.5 & 0.7 \\
\hline & & & 0.7 & 0.1 \\
\hline & & & 1.8 & 0.8 \\
\hline \multirow{7}{*}{ Gravel layer } & \multirow{7}{*}{100} & \multirow{7}{*}{7} & 2.8 & 1.4 \\
\hline & & & 2.1 & 1.5 \\
\hline & & & 2.1 & 1.7 \\
\hline & & & 4.3 & 3.9 \\
\hline & & & 0.7 & 0.1 \\
\hline & & & 1.3 & 0.7 \\
\hline & & & 2.8 & 1.9 \\
\hline
\end{tabular}

Table A6. Summarized aspect ratios for all layers from Au-pits (6 - 8) at Mari.

\begin{tabular}{|c|c|c|c|c|}
\hline Horizon & Thickness $(\mathrm{cm})$ & Number of pebbles & Long axis $(\mathrm{cm})$ & Short axis $(\mathrm{cm})$ \\
\hline \multirow{10}{*}{ Saprolite } & \multirow{10}{*}{300} & \multirow{10}{*}{10} & 0.9 & 0.4 \\
\hline & & & 2.2 & 1.4 \\
\hline & & & 2.0 & 0.9 \\
\hline & & & 1.2 & 0.6 \\
\hline & & & 1.5 & 1.1 \\
\hline & & & 2.4 & 2.4 \\
\hline & & & 1.8 & 0.9 \\
\hline & & & 1.4 & 0.4 \\
\hline & & & 2.5 & 2.4 \\
\hline & & & 1.3 & 0.3 \\
\hline \multirow{10}{*}{ Sandy layer } & \multirow{11}{*}{90} & \multirow{11}{*}{10} & 0.9 & 0.4 \\
\hline & & & 1.2 & 0.4 \\
\hline & & & 1.7 & 0.5 \\
\hline & & & 0.7 & 0.4 \\
\hline & & & 0.9 & 0.3 \\
\hline & & & 1.3 & 0.4 \\
\hline & & & 1.6 & 0.4 \\
\hline & & & 1.8 & 1.0 \\
\hline & & & 1.8 & 0.8 \\
\hline & & & 1.8 & 1.0 \\
\hline \multirow{11}{*}{ Gravel layer } & & & 5.0 & 4.9 \\
\hline & \multirow{10}{*}{70} & \multirow{10}{*}{11} & 6.6 & 5.2 \\
\hline & & & 8.9 & 6.8 \\
\hline & & & 10.0 & 6.6 \\
\hline & & & 6.2 & 2.6 \\
\hline & & & 4.6 & 2.5 \\
\hline & & & 3.4 & 1.5 \\
\hline & & & 3.6 & 3.1 \\
\hline & & & 12.2 & 12.0 \\
\hline & & & 10.7 & 5.2 \\
\hline & & & 12.5 & 10.0 \\
\hline
\end{tabular}

